\title{
Psychological Angst in James Joyce A portrait of an artistas a young man and D.H Lawrence Sons and lovers: a comparative exegesis
}

\author{
Aman Deep Singh \\ Department of English PhD Scholar Central university of Rajasthan India
}

\begin{abstract}
My paper aims at describing the psychological complexities and internal feud which cripples the protagonists of the two novel who cannot reconcile with antithetical pulls of love and lust, art and beauty, religion and aesthetics, ethics and hypocrisy, self and society, and 'struggle to signify'. A psychoanalysis of the novels is the key aspect to explore the self in modernity, arguing that it represents the culmination of a tradition, which grew out of the confessional practices introduced by the church. Key terms such as 'desire', 'id', 'ego', 'super ego', 'oedipal complex', 'schizo-analysis', 'subject', 'subjectivity' and 'unconscious' acquaints the reader with the psychological angst and the fragmented nature of modernism. This comparative study attempts to evaluate the antithetical pulls of self versus society and dimensions of cultural and hegemonic values which cause psychological turmoil and an inner turbulence.
\end{abstract}

\section{Introduction}

James Joyce and D.H Lawrence were the pioneers of their time and are also known as the modern novelists. "Modernism" signifies a set of aesthetic tendencies associated with writers like Joyce, Eliot, Lawrence and Pound who wrote around 1920's in defiance of the decadent Victorian and Edwardian tradition replacing it what is now called "High Modernism". James Joyce (1882-1941) was a daring innovator, and he started his career as a novelist with realistic pictures of life, but with a special emphasis on the exploration of the states of human consciousness. James Joyce, Virginia Woolf, and Dorothy Richardson were the greatest among the psychological novelists of the twentieth century. They discarded the conventional concept of time and directed their attention to exploration of the layers of human consciousness and even the unconscious. They are called "stream-of-consciousness novelist". They attempt to portray life and reality by setting down everything that goes on in the mind of a character, notably all those chaotic thought-sequences which occupy our idle and somnolent moments, and to which, in real life, we pay little attention. Influenced by the new psychologistsFreud, Jung and Adler- they came to recognize the human consciousness as a flowing stream which linked the past, present, and to come in an organic unity, and gave them all a never-changing reality. In a way stream of consciousness novel bear a close resemblance to 'Imagist' poetry.

Lawrence achievement as a great modern novelist came to be recognized long after his death in 1930. D.H Lawrence came out with a new kind of novel based on a deep study of sexual passion combined with mystic symbolism and a prophetic strain. D.H Lawrence was extremely critical of modern sophisticated civilization which believed in curbing man's natural instinct. To discover a free flow of passionate life became for him almost a mystical ideal. Lawrence wrote in the preface of his very controversial novel 'Lady Chatterley's lover': "I want men and women to be able to think sex fully, completely, and clearly." Here, then the "Fleshy school" of the novel. 'Sons and Lovers', like other novels of Lawrence, is unmistakably autobiographical. It tells how the sons are so dominated by their mother's affection that when they grow up they cannot love, but lust. According to Middleton Murry, Lawrence belongs to no school and no tradition, except the "tradition of himself". Lawrence invented a language in which sexual experience can be described correct to its every fine shade. As Lawrence concentrated on man-woman relationship, it was inevitable for him to deal intimately with the theme of sex.

Both 'The portrait of an artist as a young man' and 'Sons and Lovers' combine the elements of the 'Buildungsroman' and 'kunstlerroman'tradition. A'Buildungsroman' is a novel describing the gradual education of the protagonist, while 'Kunstlerroman' explores the development of an artistic sensibility. Comparison of the two texts, and its protagonists, however, reveal crucial between them. The 'Kunstlerroman', though it reverses the more normal procedure of applying the methods of art to the subject of reality, is the only conception of the novel that is specialized enough to include 'A portrait of the Artist'. In 1913, the year before Joyce finished his book, D.H Lawrence had published his own portrait of the artist, 'Sons and Lovers'. Both books convey the cl austral sense of a young intelligence swaddled in convention and constricted by poverty, and the intensity of its first responses to aesthetic experience and life at large. The extent to which Lawrence 
warms to his theme is the measure of Joyce reserve. Characteristically, they may be reacting from the very different institutions behind them- evangelical English Protestantism and Irish catholic orthodoxy- when Lawrence dwells on the attraction of life, and Joyce on its repulsion's. The respective mothers of the two artistsStephen Dedalus and Paul Morel- play a similar role, yet May Dedalus is wraith beside the full-bodied realization of Mrs Morel. The characters in 'Sons and Lovers' seem to enjoy an independent existence, while in the 'Portrait of an Artist' they figure in the hero's reveries and resentments.

Joyce treatment of childhood is unrelieved in its sadness: endless generation of choirs of children sounded, for Stephen Dedalus, the same note of pain and weariness that Newman had heard in Virgil. 'All seemed weary of life even before entering it.' The protagonists of both the novels are quite complex, and both are a faithful and autobiographical portrait of their respective creators.Stephen is a hero who breaks through the restrictions of family, church, and nation to shape his own destiny according to his inner lights. He overcomes the limitations of his culture and environment, and soars into higher realm. Critics, while accepting that it was Joyceintention to present a heroic Stephen because he comes across a bit of a prig and tends to isolate himself from everything around him-not admirable qualities. The presentation of Stephen is riddled with deliberate irony. He seems self-absorbed and even arrogant, refusing to be sociable or to blend in with his community. He seems obsessed with his own theories of art and beauty, which separate him from human community rather than uniting him with it. In this way the 'Portrait of an Artist as a young man' is an ironic book by the older, and presumably wiser, James Joyce at his youthful self.The most striking quality of Stephen and Paul's character is their introverted temperament. In Stephen Dedalus' case this is indicated in the picture of his early childhood.Thus, the readers are told that during a football session at school, he "kept on the fringe of his line, out of sight of his perfect, out of reach of the rude feet, feigning to run now and then. He felt his body small and weak amid the throng of players and his eyes were weak and watery." These lines show that Stephen feels himself to be an outsider. He is withdrawn introspective and sensitive. He seems to be on the defensive, and he adopts cunning tactics to cover up his weak position and avoid commitment. This introverted tendency is also seen in his effort to try to realize a subjective vision in the external world: "But you could not have a green rose, but perhaps somewhere in the world you could." As an adolescent, he begins to resist the claims of external world, setting up his own subjective values and interest against the values and interest of social institutions. It is his introverted temperament that provides the basis of his aesthetic attitude. Stephens introversion as an adult is the basis of a defensiveness which uses a more highly developed form of the same weapons he had used as a child: "I will not serve that in which I no longer believe, whether it call itself my home, my fatherland, or my church: and I will try to express myself in some mode of life or art as freely as I can and as wholly as I can, using for my defense the only arms I allow myself to use- silence, exile, and cunning." Stephens isolation, his alienation from family, school, religion, nation, culminating in his voluntary exile is, at all stages, a logical result of his fundamental introverted nature. He seeks and finds his own identity by resisting all collective relationships.

In D.H Lawrence's 'Sons and Lovers', Paul Morel is unusually dependent on his mother's care. Paul's neurosis in his early years makes him self-conscious when he grows up. He turns into hypersensitive introvert to whom any touch with external reality is an agonizing experience. He suffers very much from the first contact with anything. His first visit to school is a nightmare for him. When he goes to collect the weekly wages of his father, he suffers at heart just because the people there speak to him in their improper manner. Paul feels the entire experience so tormenting that he resolves never to go there again. Later, when he is required to look for a job, he goes through the same agonies of shrinking self-consciousness. Paul feels embarrassed to go to library to read advertisements and is haunted by the idea that people must be thinking that since he cannot get a job he must be living on his mother's support. He suffers exactly in the same manner when he goes to Jordan's to appear for an interview and he feels so nervous during the interview that he fails to read or answer even a single question. Lawrence examines the effects of the overwhelming affection of a mother on the sons. The novel is quite autobiographical as Paul Morel is a reflection of Lawrence himself. Towards the end of the novel, Paul is a broken and disintegrated man.

One of principal traits of both, Stephen and Paul, is their egocentricity. This egocentricity derives from their introverted nature.From this egocentricity proceed various manifestations of pride. It is the egocentricity of Paul and Stephen which finds its natural expression not in love, but in lust. It is lust which makes Stephen visit prostitutes frequently, and it is this lust which does not allows Paul to love Miriam and later results in a sexual intercourse with Clara Dawes, wife of Baxter Dawes. In describing the agony of frustrated lust, Joyce makes its obscenity plain. Stephen clearly recognizes his state of mortal sin and he acknowledges the interconnection of his lust and pride. It is possible to see the wading girl episode as the complete deliverance of Stephen from the restraints imposed on his sexuality by the church. Joyce seems to think that certain aspects of egocentricity are essential in the development of an artist. For instance, it would perhaps not have been possible for Stephen to find his true identity or his real vocation as artist without the following expressions of his egocentricity: Firstly, he feels compelled to excel at Belvedere in essay writing; secondly, he shows his defiant non-conformism in his 
encounter with Heron; thirdly, he is so rebellious that he identifies himself with Lucifer; lastly, his pursuit of individuality is ruthless, and it is this pursuit which shatters the collective ties to family, nation and religion. In case of Paul Morel, the protagonist of 'Sons and lovers', one can see D.H Lawrence's perpetual search for the archetypal human relationship and his preoccupation with the love ethic and the profound split caused by the imbalance or "power cast" of most relationship which are so nakedly revealed. Paul Morel's imprisoning relationship with his mother cripples all his other relationship. What begins as a warm wholesome attachment between mother and child later becomes shaded with incestuous overtones and ends as a controlling force in Paul's life. The result for Paul seems to be the inability to respond to the women in his life, both, sexually and unconsciously. With Miriam hi first love, Paul's primary contact is spiritual and cerebral, and once the mutual attraction crumbles into bitterness because neither can respond to their "physical life force" or integrate it into their attempted communion of souls. Part of the difficulty in this relationship, Lawrence seems to be implying is that Miriam's attraction to Paul is that she rejects the spontaneous physical response available to them and prefers "the higher level of affection and spiritual communion and intellectual interchange". When Paul, physically aroused, find no natural response in the girl who seems to love him, he is confused, helpless and becomes cruel and is unable to continue the mental and spiritual relationship with the girl because his mother, alone, owns his soul. The relationship is ruptured, Paul's personality suffers a kind of tearing or splitting, another favorite image of Lawrence, and in his next relationship Paul realizes at some unconscious level that he must leave his soul somewhat free for his mother and participate and participate on a kind of detached physical level. Thus, in his relationship with Clara, it is primarily bodily maleness of Paul bonding with the bodily femaleness. Obviously the danger is to oversimplify the Paul-Miriam and Paul-Clara relationship. It is true that the contact with Clara puts Paul at least temporarily into richer contact with his own body, his phallic consciousness, as Lawrence would say, whereas in his sterile relationship with his mother and Miriam, Paul has to forego his fuller consciousness. After lovemaking he refers to "coming out of some unconsciousness" to be "carried by life" in love. Yet, a novice, Paul fears the power Clara has over him and finally lets their relationship wither as the demand of a sick and dying mother calls him home. The balance of power in relationship seems to be an essential concern of D.H Lawrence, since it appears over and over again to be responsible for death of love. Lawrence's men and women will not be controlled, possessed or lost in another individual reality. Relationship to them must not be a mere matter of perfect blending with the resultant loss of self hood, they are telling us. Lawrence's life itself would illustrate the struggle to achieve balance in relationship and definition of self as wrought against the outlines of another being.

James Joyce through Stephen secularizes Aquinas. Joyce adheres to the Thomist categories, but interprets them to suit his own purpose. Yet, in doing so, he uses much of Aquinas and does not so much dispute as distort the scholastic argument. At least one important doctrine that he accepts completely: the identification of truth as the conformity of mind and object he finds useful because it provides him with the justification of absolute, psychological standards for art and a defense against a charge that his theory is that of a dilettante or an 'Art-for-Art's sake' advocate. Each of the other principles, however, he interprets against the spirit, if not the letter, the Summa-in secular, in mundane terms that permit him to discard the supernatural implications of Thomist doctrine. Stephens theory of aesthetics is original, logical and totally uncompromising. The aesthetic lecture has a purely intellectual appeal. There are three main points in Stephens aesthetic theory: the distinction between static and dynamic; the three kinds of art-lyric, epic and dramatic; wholeness, harmony, and radiance as requirements of art and stages of his apprehension. This amounts to a theory of impersonality and autonomy. For Stephen, art is all alone, as separate from morality as he himself from society. Kinetic art, whether moral or immoral, is bad because it arouse desire, inviting action rather than contemplation. His rejection of pornography is understandable as his rejection of the didactic. Stephens theory is obviously formalist, is a theory of 'Art for art sake', and it links him with Oscar Wilde. Stephens three requirements for art- Integritas(wholeness), selfsufficient, like Stephen. Harmony is apprehended by analysis. Wholeness and harmony together produce radiance. Stephens aesthetic discourse is a theory of impersonality that he shares with T.S Eliot. The three kinds of art enunciated by Stephen- lyric, epic and dramatic- rise in this order from the personal to the impersonal, and acquire merit as they rise. The lyric commonly means a short song; an epic is a long narrative poem written in grand style; and the dramatic means a play. He uses these terms to distinguish three attitudes of writers towards their work. A lyric writer, incapable of distance, is one with his work. An epic writer stands between his work and audience showing it to them. The dramatic writer has distanced himself to the point of disappearance. His work is alone, speaking for itself. In Stephen's sense, therefore, a lyric poem could be dramatic, depending on the writer's attitude and position. His preference for dramatic, impersonal art harmonises with his insistence upon autonomy. The triumph of personality consists in the achievement of impersonality. Stephen calls his theory 'applied Aquinas'. Many critics regard Stephen's theory as Joyce's own. They have applied to his works to find if they are lyric, epic, or dramatic. Some critics have found 'A Portrait of an artist as a young man'to be lyric, 'Ulysses' to be an epic, and 'Finnegans Wake' to be dramatic. One critic finds all three kinds in 'A Portrait of an Artist' which, according to him is a lyric at first, epic in the middle, and dramatic at the end, 
though the diary entries remain a problem. However, harmonious and radiant Joyce works, Stephen's theory is inadequate nevertheless for estimating them. It is in fact to narrow as it lacks humanity, compassion, charity, and understanding, and all these Joyce works have. Even in Stephen's explicit theory, there is an important element of subjectivity which is significant in the creation of beauty than it is in the perception of beauty. Although Stephen calls the final stage of his aesthetic impersonal, he speaks of aesthetic images not as being discovered in the thing, but rather as being conceived in the artist's imagination. Although, the artist 'refine himself out of existence', he does not take what would seem to be the only alternative, the objective representation of life and "the aesthetic image in the dramatic form is life purified in and re-projected from human imagination".

Where James Joyce presents the theory of Thomas Aquinas through Stephen Dedalus, D.H Lawrence presents the theory of 'Oedipus complex' through the character of Paul Morel. 'Oedipus complex' is a psychoanalytic theory of sex. It explains the love in a child for parents of opposite sex. The term is derived from the Thebian hero, Oedipus of Greek legend who unknowingly slew his father and married his mother. The opposite of 'Oedipus complex' is 'Electra complex'. Freud's Oedipus complex to children is between the age of three and five years. In the beginning it is unconscious and instinctive, and come as a natural result of child's dependence on the mother for food, warmth and comfort. Human beings are born lovers and the mother is one overwhelming presence of those early days, the source from which all good things flow, so that childhood is full of sex's omnipotence. From her one learns how to express affection and maternal caress an intimate feeling of oneness which we get from her from the easy analogies to sex when we feel a conscious passion for another individual of opposite sex. Meanwhile the influence of father and other people around the child is also felt. It is a slow and gradual process of transference, which continues through childhood and puberty. Our parents are always there in our consciousness and they become our ultimate standards by which we judge others and exercise the most potent influences over our sex or love choice. The boy chooses a woman who resembles his mother as closely as possible, and a girl chooses a man who resembles her father. This is, according to Freud, the psychological basis of sex, the normal evolution of sex from the first maternal caress is finally accomplished when an individual definitely transfer his allegiance to a mate chosen by him and steps out of the family circle in which he has lived from infancy. In case of any deviation, due to any cause, the sexual life of an individual is bound to be effected as abnormal. In 'Sons and Lovers', Lawrence weaves this knowledge into fiction and shows how Paul Morel's 'Mother-Fixation' makes it impossible for him to love another woman in life, who was not having his mother's 'Imago' or his hatred for his father. In 'Sons and Lovers', mother-fixation, the conflict of love and sex, marriage and adjustment, sensual and spiritual love, all these constitute to become one whole. The psychological abnormality born with Paul develops in him mother-fixation and towards the end he is left a miserable man looking for life in the future. Like a modern novel, 'Sons and Lovers' ends without a solution of problem but with a hope in time to come.

D.H Lawrence and James Joyce's novel have all the aspects of a modern novel and their protagonists can be termed as 'Modern hero'. Lawrence and Joyce spent their life in an era during which the nineteenth century values were diminishing, but the new values were yet to be developed. Industrialism, science and psychology had brought in new factors in the development of human history, and conflict of values was natural. The works of James Joyce and D.H Lawrence portrays the change and thus lay foundation of modern novel.

\section{References}

\footnotetext{
[1]. Black, Michael.Sons and Lovers. Cambridge: Cambridge University Press, 1992.

[2]. Brown, Richard,Joyce and Sexuality. Cambridge: Cambridge University Press, 1985.

[3]. Bulson, Eric.The Cambridge Introduction to James Joyce. Cambridge: Cambridge University Press, 2006.

[4]. Dix, Carol. D.H Lawrence and women. London: Macmillan, 1980.

[5]. Leavis, F.R. D.H Lawrence: Novelist. Harmondsworth: Penguin, 1964.

[6]. Mikula, Maja. Key concepts in Cultural Studies. Palgrave Macmillan,2008.

[7]. Sanders, Scott. D.H Lawrence: The World of Five Major Novels. New York: Viking Press, 1973
} 